\title{
VIETNAM AT THE CROSSROADS - AN ANALYSIS AND DRAFT FOR REFORM OF THE VIETNAMESE ECONOMY
}

\author{
By Hansjörg Herr and Rainer Stachuletz ${ }^{1}$
}

As the result of the "Doi-Moi" reform policy, Vietnam has experienced a remarkable phase of growth since 1986. In this period the Gross Domestic Product (GDP) quadrupled. Since the population of Vietnam (about 88.5 million people in 2010) is currently growing by more than one million people annually, the increase in per capita income lags behind GDP growth, but still reached 2900 U.S. dollars in 2009, which ranks $165^{2}$ in the world (see Table 1). In order to prevent its per capita income from falling off because of this huge increase in population growth, Vietnam needs a real GDP growth of over 5\%. Although the poverty rate was decreased from $58 \%$ to 13\% between 2003 and 2008, considerable regional disparities especially between rural and urban areas continue to persist ${ }^{3}$.

Table 1

Selected macroeconomic indicators of Vietnam 2000 -2009

\begin{tabular}{|c|c|c|c|c|c|c|c|c|c|c|}
\hline Macro Indicators & 2000 & 2001 & 2002 & 2003 & 2004 & 2005 & 2006 & 2007 & 2008 & 2009 \\
\hline Real GDP Growth in \% & 6.80 & 6.9 & 7.1 & 7.3 & 7.8 & 8.4 & 8.2 & 8.5 & 6.2 & 5.32 \\
\hline GDP per Capita (PPP in USD & 1423 & 1535 & 1648 & 1814 & 1949 & 2142 & 2364 & 2607 & 2793 & --- \\
\hline GDP per Capita (in USD) & 402 & 421 & 440 & 492 & 553 & 642 & 730 & 843 & 1052 & 1064 \\
\hline Exports in Mio USD & 14483 & 15029 & 16706 & 20149 & 26485 & 32447 & 39826 & 48561 & 62685 & 56600 \\
\hline Imports in Mio USD & 15637 & 16218 & 19746 & 25256 & 31969 & 36761 & 44891 & 62765 & 80714 & 68800 \\
\hline Balance of Trade in Mio USD & -11535 & -1188 & -3039 & -5106 & -5483 & -4314 & -5064 & -14203 & -18029 & -12200 \\
\hline Current Account in Mio USD & 642 & 670 & -419 & -1946 & -957 & -560 & -164 & -6992 & -10787 & -7440 \\
\hline Capital Account in Mio USD & -526 & -476 & 883 & 4097 & 2379 & 3087 & 3088 & 17540 & 12341 & 11869 \\
\hline Net Inflow FDI in Mio USD & 1101 & 1252 & 2023 & 1894 & 1763 & 1889 & 2315 & 6550 & 9279 & 7600 \\
\hline Remittances in Mio USD & --- & 2000 & 2714 & 2700 & 3200 & 4000 & 4800 & 5500 & 7200 & 6840 \\
\hline Budget Deficit (\% v. GDP) & -5.0 & -5.0 & -4.5 & -7.2 & -4.5 & -4.5 & -1.1 & -5.3 & -4.7 & -8.2 \\
\hline Gross Capit. Form. (\% GDP) & 27.65 & 29.15 & 31.14 & 33.35 & 33.26 & 32.87 & 33.35 & 38.27 & 34.61 & 34.52 \\
\hline
\end{tabular}

Source: IMF Country Reports Vietnam 2003-2010; General Statistics Office of Vietnam (2010)

Vietnam's great success should not distract us from a number of problems that have developed over the years. The trade deficit in Vietnam accounts for about $15 \%$ of GDP. Due to considerable transfers from Vietnamese living abroad (more than $5 \%$ of
GDP), current account deficits are far less but still high. Vietnam has experienced a surge in foreign direct investment flows since the country joined the WTO in 2007. Annual net foreign direct investment ${ }^{4}$ has recently reached 6.8 billion USD, almost one quarter

\footnotetext{
${ }^{1}$ Hansjörg Herr is Professor of Supranational Integration at the Berlin School of Economics and Law. He is also the Academic Director of the Master's programme Labour Policies and Globalisation of the Global Labour University. Rainer Stachuletz is Professor of Finance at the Berlin School of Economics and Law. He is currently acting as consultant for the State Bank of Vietnam at the Banking Academy of Vietnam in Hanoi. He is Academic Director of the study programme of the Berlin School of Economics and Law in Vietnam.

${ }^{2}$ The value is the result of the calculation of a basket of goods. In nominal terms the per capita income is just above 1000 USD

${ }^{3}$ All statistical data have been taken from the General Statistics Office of Vietnam - Statistics Documentation Centre - (GSO) Ba Dinh Ha Noi 68 Hoang Dieu. Internet: www.gso.gov.vn.

${ }^{4}$ Disbursements
} 
of Vietnam's total investments. However, the structure of foreign direct investment is problematic (see below). Vietnam realises high budget deficits consistently, most recently due to considerable governmental expenditure for economic stimulus packages, the total volume of which has reached nearly $10 \%$ of GDP. In addition, the integration of the country in the world market, the danger of a real estate bubble, as well as widespread corruption all add to Vietnam's current problems.

This article analyses on the one hand the current situation in Vietnam, and on the other, outlines a strategy for reform. We understand this as a contribution to the controversial debate, to which we offer our position.

\section{Extended workbench and Dutch Disease}

With a percentage of $41.6 \%$ of GDP, the industrial sector captured the leading position for the year 2009, just ahead of the service sector with $41.4 \%$ and that of agriculture, fishing and forestry with $17.1 \%$. To a large extent the last 20 years have been influenced by the increasing significance of the industrial sector, but also by the service sector emerging at the same time. After the stormy development of the industrial sector - with growth rates of well over $10 \%$-in the first years after the end of the western embargo (1992-1996) there followed a development phase of industrial growth at about $10 \%$. The growth within the service sector developed in a similar way at this time, while agriculture lagged behind consistently. Especially for the labour market, agriculture continues to play a decisive role, as about $60 \%$ of employable people work in this area.

Despite high growth rates structural weaknesses can be detected throughout Vietnam's industries. In this respect the growing importance of the industrial sector hides the fact that it has not been able to develop a growth dynamic in technologically advanced segments with high value added. Vietnam's industry concentrates to a large extent (about $50 \%$ of total industrial output) on producing raw materials, mostly at a basic technological level and a low level of value added. Due to its considerable advantage in labour costs Vietnam also takes on the role of an extended workbench (outsourcing) in light industries of its Asian neighbours, or as their strategic location for the completion of export goods (e.g. shoes or textiles) that are subject to import restrictions in the USA and the European Union.

Table 2

Structure of nominal Gross Domestic Product in Vietnam 2000 - 2009*

\begin{tabular}{|lrrrrrrrrr|}
\hline $\begin{array}{l}\text { Gross Domestic Product By Sources } \\
\text { (in BII. VND) }\end{array}$ & 1995 & 2000 & 2005 & 2006 & 2007 & 2008 & $\begin{array}{l}\text { Prel. } \\
2009\end{array}$ & $\begin{array}{l}2000 \\
\text { in \% }\end{array}$ & $\begin{array}{l}2009 \\
\text { in \% }\end{array}$ \\
Total GDP & 228892 & 441646 & 839211 & 974266 & 1143715 & 1485038 & 1658389 & \\
Agriculture and forestry & 55555 & 93450 & 143037 & 160462 & 186462 & 271477 & 285030 & $24.3 \%$ & $17.2 \%$ \\
Fishing & 6664 & 14906 & 32947 & 38335 & 46124 & 58409 & 61756 & $2.9 \%$ & $3.7 \%$ \\
Mining and quarrying & 11009 & 42606 & 88897 & 99702 & 111700 & 146607 & 165310 & $4.8 \%$ & $10.0 \%$ \\
Manufacturing & 34318 & 81979 & 173122 & 207027 & 243142 & 302136 & 333166 & $15.0 \%$ & $20.1 \%$ \\
Electricity. gas and water supply & 4701 & 13993 & 28929 & 33464 & 39869 & 47169 & 58592 & $2.1 \%$ & $3.5 \%$ \\
Construction & 15792 & 23642 & 53276 & 64503 & 79712 & 95696 & 110255 & $6.9 \%$ & $6.6 \%$ \\
Wholesale/retail trade; repair & 37491 & 62836 & 113768 & 132794 & 156442 & 212139 & 244933 & $16.4 \%$ & $14.8 \%$ \\
Hotels and restaurants & 8625 & 14343 & 29329 & 35861 & 44992 & 57067 & 67394 & $3.8 \%$ & $4.1 \%$
\end{tabular}




\begin{tabular}{|c|c|c|c|c|c|c|c|c|c|}
\hline Transport. storage and communications & 9117 & 17341 & 36629 & 43825 & 51118 & 66359 & 72412 & $4.0 \%$ & $4.4 \%$ \\
\hline Financial intermedation & 4604 & 8148 & 15072 & 17607 & 20756 & 27215 & 31617 & $2.0 \%$ & $1.9 \%$ \\
\hline Scientific activities and technology & 1405 & 2345 & 5247 & 6059 & 7065 & 9296 & 10581 & $0.6 \%$ & $0.6 \%$ \\
\hline Real estate. renting and business activities & 12392 & 19173 & 33635 & 36814 & 43509 & 53743 & 60234 & $5.4 \%$ & $3.6 \%$ \\
\hline Public admin.. defense; social security & 8278 & 12066 & 23038 & 26737 & 31310 & 41279 & 47042 & $3.6 \%$ & $2.8 \%$ \\
\hline Education and training & 8293 & 14841 & 26948 & 30718 & 34843 & 38261 & 42780 & $3.6 \%$ & $2.6 \%$ \\
\hline Health and social work & 3642 & 5999 & 12412 & 14093 & 16160 & 19178 & 21537 & $1.6 \%$ & $1.3 \%$ \\
\hline Recreational. cultural. sporting activities & 1259 & 2558 & 4158 & 4617 & 5200 & 5842 & 6964 & $0.6 \%$ & $0.4 \%$ \\
\hline Party and membership organis. activities & 223 & 614 & 1054 & 1217 & 1425 & 1909 & 2046 & $0.1 \%$ & $0.1 \%$ \\
\hline community. soc. pers. service activities & 4979 & 9853 & 16293 & 18789 & 21959 & 28704 & 33843 & $2.2 \%$ & $2.0 \%$ \\
\hline Private households with employed persons & 545 & 953 & 1421 & 1642 & 1927 & 2551 & 2898 & $0.2 \%$ & $0.2 \%$ \\
\hline
\end{tabular}

The competitive weakness of the (210\%), fishing (132\%) or the logistics industrial sector is confirmed with a look and communications sector (308\%). Only at the sectors productivity. Productivity in the finance industry $(33 \%)$ and the totally manufacturing - which increased $110 \%$ from inefficient housing sector $(-22 \%)$ have 1999 until 2009 - lags far behind agriculture faired worse than manufacturing.

Table 2

Development of Sector Productivity 2000 - 20095*

\begin{tabular}{|lrrrrrrr|}
\hline & $\mathbf{2 0 0 0}$ & $\mathbf{2 0 0 4}$ & $\mathbf{2 0 0 5}$ & $\mathbf{2 0 0 6}$ & $\mathbf{2 0 0 7}$ & $\mathbf{2 0 0 8}$ & $\mathbf{2 0 0 9}$ \\
\hline Average Productivity & $\mathbf{1 1 . 7}$ & $\mathbf{1 7 . 2}$ & $\mathbf{1 9 . 6}$ & $\mathbf{2 2 . 2}$ & 25.3 & $\mathbf{3 2 . 0}$ & $\mathbf{3 4 . 7}$ \\
Agriculture and forestry & 4.0 & 5.6 & 6.2 & 7.0 & 8.2 & 12.0 & 12.4 \\
Fishing & 15.1 & 19.6 & 22.1 & 24.3 & 27.6 & 33.5 & 35 \\
Mining and quarrying & 166.6 & 223.5 & 259 & 265.5 & 274.6 & 328.7 & 346.2 \\
Manufacturing & 23.1 & 30.1 & 32.8 & 36.1 & 39.8 & 46.3 & 48.6 \\
Electricity. gas and water supply & 169.2 & 182.9 & 190 & 190.2 & 197.8 & 203 & 223.1 \\
Construction & 27.7 & 23.2 & 26.5 & 29.8 & 34.3 & 38.6 & 40.9 \\
Wholesale/retail trade; repair & 16.1 & 20.3 & 25.2 & 27.9 & 31.4 & 41.3 & 46.4 \\
Hotels and restaurants & 20.9 & 29.8 & 41.7 & 49.2 & 58.7 & 71.9 & 82.5 \\
Transport. storage and communic. & 14.8 & 25.3 & 33.1 & 38.8 & 44.6 & 56.9 & 60.4 \\
Financial intermedation & 108.4 & 102 & 105.2 & 103.6 & 105 & 129.4 & 144 \\
Scientific activities and technology & 124.7 & 172.6 & 232.2 & 242.4 & 273.8 & 346.9 & 387.6 \\
Real estate. renting and business activities & 300 & 241.4 & 242.3 & 221.6 & 213.9 & 223.7 & 233.6 \\
Public admin.. defense; social sec. & 32.1 & 35.6 & 15.1 & 16.7 & 18.6 & 23.3 & 25.9 \\
Education and training & 14.9 & 19.7 & 23.8 & 25.4 & 27.3 & 28.6 & 31.1 \\
Health and social work & 26.6 & 31.5 & 37.6 & 40.7 & 44.6 & 50.2 & 55 \\
\hline
\end{tabular}

${ }^{5}$ The General Statistics Office in Vietnam defines productivity to be the ratio of sector specific Gross National Product (GNP) and the number of fully employed people in the sector. Source: General Statistics Office of Vietnam (2010) 
The internal structure of the Vietnamese low level of manufacturing and value added, economy corresponds with the integration in the international division of labour: Vietnam sells services in tourism and plays the role of an extended workbench.

exports a huge amount of raw materials at a

Table 3

Structure of foreign trade in Vietnam 1999 - 2008

\begin{tabular}{|c|c|c|c|c|c|c|c|c|c|c|}
\hline & 1999 & 2000 & 2001 & 2002 & 2003 & 2004 & 2005 & 2006 & 2007 & 2008 \\
\hline EXPORTE TOTAL in Mio USD & 11541 & 14483 & 15029 & 16706 & 20149 & 26485 & 32447 & 39826 & 48561 & 62685 \\
\hline IMPORTE TOTAL in Mio USD & 11742 & 15637 & 16218 & 19746 & 25256 & 31969 & 36761 & 44891 & 62765 & 80714 \\
\hline Balance of Trade in Mio USD & -201 & -1154 & -1189 & -3040 & -5107 & -5484 & -4314 & -5065 & -14203 & -18029 \\
\hline Rohstoffe / Grundstoffe Exporte & 5996 & 8079 & 8010 & 8290 & 9397 & 12554 & 16101 & 19227 & 21658 & 27699 \\
\hline Rohstoffe / Grundstoffe Importe & 2265 & 3528 & 3686 & 4201 & 5283 & 7318 & 9308 & 11481 & 15421 & 21766 \\
\hline Balance of Trade (Commodities) & 3732 & 4551 & 4324 & 4089 & 4115 & 5237 & 6793 & 7746 & 6237 & 5933 \\
\hline Manufactured products Exports & 5541 & 6398 & 7019 & 8415 & 10748 & 13928 & 16341 & 20592 & 26886 & 34626 \\
\hline Chemical and related products, n.e.s & 147 & 159 & 222 & 262 & 340 & 421 & 536 & 792 & 1029 & 1450 \\
\hline Manufactured goods classified by materials & 865 & 911 & 990 & 1125 & 1355 & 1890 & 2165 & 2926 & 3976 & 6398 \\
\hline Machinery, transport and equipments & 978 & 1276 & 1399 & 1337 & 1793 & 2562 & 3145 & 4195 & 5601 & 7368 \\
\hline Miscellaneous manufactured articles & 3551 & 4052 & 4408 & 5691 & 7260 & 9055 & 10495 & 12679 & 16281 & 19409 \\
\hline Commodities not clasified elsewhere & 5 & 6 & 0 & 2 & 4 & 3 & 5 & 7 & 18 & 361 \\
\hline Manufactured products Imports & 9470 & 12101 & 12532 & 15532 & 19792 & 24084 & 26633 & 31531 & 46028 & 56219 \\
\hline Chemical and related products, n.e.s & 2040 & 2402 & 2490 & 2933 & 3623 & 4694 & 5310 & 6317 & 8369 & 10298 \\
\hline Manufactured goods classified by materials & 2736 & 3402 & 3729 & 5415 & 6672 & 8859 & 10172 & 12164 & 17062 & 20113 \\
\hline Machinery and transport equipment & 3453 & 4711 & 4865 & 5758 & 7922 & 8737 & 9252 & 10806 & 17860 & 22425 \\
\hline Miscellaneous manufactured articles & 1241 & 1586 & 1447 & 1427 & 1575 & 1795 & 1899 & 2244 & 2737 & 3384 \\
\hline Commodities not clasified elsewhere & 7 & 8 & & 13 & 181 & 567 & 820 & 1879 & 1316 & 2728 \\
\hline Balance of Trade Manufactured Products & -3930 & -5704 & -5513 & -7117 & -9044 & -10157 & -10292 & -10939 & -19142 & -21594 \\
\hline
\end{tabular}

Source: General Statistics Office of Vietnam (2010)

In 2008 the balance of trade showed

In the Vietnam example we a record deficit of about 18 billion USD. Although Vietnam achieved a surplus of almost 6 billion USD in the area of raw and basic materials, its negative balance for manufactured goods amounted to a spectacular 22 billion USD. This intensifies the impression of a country struggling but currently unable to develop an export economy on a technological and high value added course.

recognise tendencies of Dutch Disease: The portion of unprocessed raw materials is considerable (in 2008 estimated at 28 billion USD from a total of 63 billion USD); in addition the export industry is oriented towards labour cost advantages. In all of these factors harbour the huge risks of a vicious circle. If the industrial sector does not develop in a qualitative way, the country won't be able to achieve adequate success in education, training, 
and research. The opportunities for the development of an ambitious industrial sector would continue to fall off. The very centre of technological development for a country like Vietnam needs to be in the area of industrial production. Even the specialisation of high-quality services (as in India) is fraught with risks and ultimately not easier to achieve than industrial development.

By virtue of its natural landscapes the development of the tourism industry constitutes an important pillar for the export economy. Tourism is however a very competitive market, with specific segments and market shares already largely distributed, while the development of a competitive tourism industry with a widespread domestic network is no piece of cake. Without wanting to dampen general enthusiasm, the most magnificent golf courses, the most exclusive resorts and other touristic accomplishments such as unique natural monuments won't be able to drive technological development in Vietnam to the extent needed. Indeed, especially in the strategic planning of luxury segments, a breadth of impulses for growth cannot be expected.

\section{solution? \\ Are direct foreign investments the}

Foreign direct investments (FDI) may bring technology and qualifications into the country, improve management skills and open new export channels. This makes FDI a potentially positive source of capital flows, in contrast to short-term oriented foreign portfolio investments and foreign bank credits (usually denominated in foreign currency). But it would be bold to classify FDI as advantageous irrespective of its structure.

With respect to FDI in Vietnam there is a problem of source. A large proportion of FDI (more than 40 Bio USD of the total amount of 194 Bio USD licensed projects until the end of 2008) originate from offshore centres, those paradises of tax evasion and other undesirable activities. It is not up to Vietnam to confront such centres, but at the same time it does make a difference whether FDI is from short-term oriented investors or from foreign companies with long-term production interests. Business models of the globally active private equity industry consist of finance from high leverage buyouts (primarily from industrial countries) or of short-term oriented finance from investors in very high-growth sectors of the emerging markets. Private equity and similar institutions prefer offshore centres with a low level of regulation. Vietnam, especially the housing sector and the tourism industry, are targets for these short-term oriented and risk-loving funds.

Just as relevant as the origin of FDI is the question as to the quality of FDI. There has been of late a jump in the growth of FDI in the housing sector which does not necessarily add technology transfer or development advantages for Vietnam. Over ten years, between 1998 to the end of $2009,23.4 \%$ of all licensed FDI was allotted to the housing sector. If hotels and restaurants are included in this real-estate category, the share is more than $35 \%$. Only in 2009 alone about 75\% (incl. hotels) of all licensed FDI was allotted to the housing area. We also have the impression that even Also in other areas the emphasis of FDI has been on low level technology and labour-cost productions with only a low level of technology transfer. This has turned Vietnam into a strategic venue for the cost reduction policies of foreign companies. Forward and backward linkages between FDI and the Vietnamese industry are relatively insignificant, and there doesn't seem to be a clear concept for industrial development.

\section{The danger of a housing bubble}

The housing sector is becoming dangerously overheated. In the western part of Hanoi, for example, the property prices 
increased by about $30 \%$ in the fourth quarter of 2009. Preferential neighbourhoods in Hanoi now demand up to 15000 USD per square meter, adding them to the world's most expensive city centre areas. This undesirable development is ignited by FDI which is now flowing freely into Vietnam's housing sector. This disturbing bubble is not only worthless in terms of industrial development; it also weakens the whole financial system. The percentage of housing finance in relation to total assets of the banking system amounts to about 35$50 \%$. The speculative aspects are obvious in the housing sector. Projects that are still in the planning stages or in the process of being built are sold numerous times; some projects are pledged three or four times for debt financing, so that the actual equity capital of many projects is waferthin (Vietnam News 2010). The leveraged risk in this sector degenerates into a game of roulette. As long as the members of the economic, political, social, and academic elite indulge themselves in the strategy of making quick money in real estate markets further development will suffer.

In Vietnam, we see the danger of substantial medium-term asset and income loss as a consequence of this housing bubble and that the financial system will be strained by non-performing credits. Low-level regulated housing markets tend to become unstable (Herr/Stachuletz 2010). Other Asian countries during their fast develop phase before the 1990s (Japan, 4 Tigers) enforced strict regulations in their housing sectors, while avoiding excesses by limiting credit and to a certain extent by establishing rigid transaction management (Stiglitz/Uy 1996).

\section{Current account deficit, domestic} demand, and currency crisis

Society's demand for goods and services determine the volume of production and income development in a situation of free production capacity and available labour. Current account deficits are identical with a demand trough, because when it is not compensated by other components, it slows down domestic growth. With its high foreign deficits, it becomes obvious that Vietnam is not following an export-oriented model of growth like many of the very successful emerging economies. Should the housing boom and the construction industry crash, Vietnam would then suffer from a chronic lack of demand last not least because of the huge deficit in foreign trade and the current account.

Current account deficits that are financed by credit lead to an increase of debt which is denominated in foreign currency. In the last ten years Vietnam has been able to realise a positive capital flow structure since capital imports were mostly in the form of FDI. Because of this and the consistently high transfers from expatriate Vietnamese, precariously high foreign debt was reduced to a low level compared with GDP. However, high current account deficits remain a threat and could cause currency crises. As the situation in 2009 has shown us, some FDI are flexible. Foreign investors can turn their backs on projects, sell shares or transfer capital and profits overseas via "designed" company internal transfer pricing very quickly. Vietnam is in a macroeconomic constellation similar to Malaysia before the outbreak of the Asian crisis in 1997 - high capital inflow in form of FDI, high current account deficit, and an asset price bubble.

\section{The financial system}

The financial system in Vietnam is to a large extent state-owned; public companies are financed by state-owned banks. One of the secrets of the high level of growth in Vietnam is the massive expansion of credit by state-owned banks that stimulate high investment and thus high domestic demand. This also explains the high proportion of investment in per cent of GDP (see Table 1). Not only Vietnam used the financial 
system to push for high investment. Also Japan in the 1950s or China after the start of the reform used a state-controlled banking system to initiate a credit-investmentincome mechanism whichled to high growth. (Herr 2008). It is difficult to tell just how much credit has been and still is decided politically. Apart from this pillar of growth, smaller companies have been created, forming a partly informal sector which is subjected to brutal capitalistic logic, usually with a low-level of technology and cut off from the official financial system. Also this sector added to economic dynamic.

This outlined largely politically controlled credit - investment - income mechanism produced high growth rates in the past, but it has also weaknesses. On the one handtheallocationofcreditlackstransparency, and there is a danger of non-performing credit that would strain the financial system. It appears to us that the banking system is currently working inefficiently due to no access to effective credit technology which is necessary to support an efficient financial system. Secondly, when the private sector is cut off from the supply of credit and is forced to develop an informal credit market, this creates new problems of efficiency.

\section{Corruption}

The functioning of the Vietnamese economy is burdened by corruption or a partially corruption like system of fees. The corruption index of Transparency International (2010) shows Vietnam at rank 120 out of 180 countries for the year 2009 . Corruption pervades almost all areas of the Vietnamese economy and administration. Since only some members of society are able to afford these corrupt payments, an overflowing corruption systematically damages not only the feeling of fairness amongst the Vietnamese people but it also leads to inefficiencies. Vietnam is fighting against corruption, but neither quick privatisation nor comprehensive legal measures alone will be able to reduce corruption measurably. Russia is a good example of this. Successful abatement of corruption begins with political will and with credible role models amongst a society's elite.

\section{Outline of a reform package}

Vietnam has high potentials for a sustainable development and will be able to make gooduse of its chances for development if they correspond with its resources and goals, as well as the careful selection of these opportunities especially in quality growth development. We are convinced that a framework for sound industrial policy is possible in a process of social dialogue, and that this will strengthen the sustainability of Vietnam's industrial and natural potentials. In the ideal case, Vietnam should design a clear industrial policy that is dovetailed with foreign policy, and at the same time pursue steady macro-economic demand management that allows for high growth. In the following we outline such a strategy. ${ }^{6}$

\section{Demand Management}

The demand for goods in a country like Vietnam has to be set up on a number of pillars. Of central importance is private and public investment demand which must be driven by a highly productive financial system that serves the real economy. Selected foreign direct investments can add support, especially in the area of technology transfer. Current account deficits are to be avoided; the aim is an export orientation, albeit without a high current account surplus. It is important to achieve sufficient domestic demand, as this is essential for dynamic domestic growth.

To stimulate domestic demand, a relatively balanced income distribution is a must. This can be achieved by the further development of job market institutions including free systems of wage negotiations

\footnotetext{
${ }^{6}$ Vergleiche dazu auch Dullien/Herr/Kellermann (2009).

${ }^{7}$ Vietnam is in an excellent position for the development of wind, biothermic, and photovoltaic energies.
} 
and a simple comprehensive social network for everyone. The ratio of government spending to GNP in developing countries needs to be sufficiently high (Stachuletz 2011). With the exception of state investments in which the government can remain indebted for longer, budget deficits should be balanced within the business cycle and not lead to an increase in the national debt. This reiterates the necessity of an established system of taxation which contributes to an acceptable level of income distribution.

\section{Industrial policy and high value-added}

All industrial and successful developing countries need to have active protection and support of its infant industries (Chang 2002). One starting point would be the systematic support of the further processing of domestic raw materials. As an important producer of foodstuffs, Vietnam could develop this area of processing, in order to improve their perspectives on producing high quality competitive products for global markets.

Of course an ecological tourism industry that is linked with the domestic economy can also play a role. Vietnam could become a role model in the area of sustainable ecological development. In order to close the energy gap requirements Vietnam will have to decide between the long-term development of regenerative, mostly de-central energy plants and the development of environmentally problematic facilities that run on fossil fuels or even the entry into atomic energy technology. Governmental investment in the infrastructure of almost all areas is substantial, as is state sponsorship of education. We are convinced that a state commission of experts who keep an eye on all of the interests in Vietnam is able to develop a sound concept for industrial development, which should then be adapted and applied continually, in line with experience and economic changes.
State protection and state support is then necessary to implement the selected development strategy.

In the ideal case, Vietnam should design a clear industrial policy that is dovetailed with foreign economic policy, and at the same time pursue steady macroeconomic demand management that allows for high growth.

\section{Direct investment and foreign trade}

FDI should be navigated in such a way that development is pushed forward and in concert with industrial policy. This includes negotiating with foreign investors as to the amount of technology they can bring into the country and to agreeing on a minimum of domestic input including manpower in Vietnam. Foreign companies should also not be given an advantage over domestic firms. When capital imports are neutralised by foreign exchange market interventions of the central bank, FDI can be connected with a balanced current account or one with a modest surplus. China is the latest example of this, although there is no reason to exaggerate such a policy. On the whole capital import controls must support such a policy. Foreign portfolio investments and the financing of domestic sectors with foreign loans are dangerous; they do not support development and should be kept to a minimum. In the meantime the word is out even for the International Monetary Fund that the liberalisation of international capital flows did not bring about success for developing countries, but rather volatility and instability of the financial systems with significant negative consequences for the real economy.

The present current account constellation is dangerous for Vietnam because it can lead to a currency crisis and at the same time can weaken domestic demand. The goal should be to balance the current account as soon as possible. It would be best to achieve a real devaluation in which the nominal exchange rate of 
the Dong remains stable, while Vietnam becomes more competitive by means of a low domestic inflation rate and increases in overall productivity.

\section{Housing markets}

For the stability of the economy the housing sector must be regulated. Foreign directinvestment in this areais fundamentally undesirable and should only be allowed in exceptional situations. In order to prevent asset bubbles credit strict credit restrictions, a capital gains tax and similar instruments must be implemented.

\section{Selective privatisation}

A large part of Vietnam's economic activity is carried out in state-owned companies. Since the country's entry into the WTO at the latest, Vietnam has joined others, at least formally, in the pursuit of a liberal market reform policy which also entails a quick privatisation. According to the Enterprise Law privatisation was targeted for 1 July 2010. However, there has actually been little change. This should not however be seen as a problem since quick privatisation did not for example help development in Russia, while China's very cautious privatisation process has developed superbly.

Companies dealing in public goods (water and energy supply, waste removal, transport, health systems, education, etc) should remain under state control as experience in industrial nations has shown. Companies of strategic importance should not be privatised. Instead, for all types of businesses including state-owned companies, the legal, social and political pre-conditions for functional management is the key. The latter is usually in place, while management functions and owner functions are strictly separated. We advocate a transformation of state-owned companies to public share companies, whereby management would be appointed and controlled rigorously. In Germany, both former and current stateowned, listed and globally active companies in all branches are examples of successfully managed state-owned companies.

Germany has also had good experience with the models of co-determination, in which worker representatives participate in overseeing management and take part in company decision-making. To oversee companies efficiently a functional financial system that can place restrictions on companies is also of importance.

\section{Financial system}

Financial systems should serve the real economy. This function can be taken over by relatively simple structured systems. For example, the central bank could set and control the credit volume of the commercial banking system with credit ceilings or window guidance. At the same time the central bank can set deposit and lending interest rates, in which positive but low real interest rates should be the aim. Commercial banks then assume a key role in credit allocation and the control of companies' efficiency.

The government can remain owner of the majority of banks, as privatising banks quickly and extensively, especially to foreigners, does not normally lead to a positive development of the whole economy. Like any other state-owned companies, state banks can be managed efficiently. The "Sparkassen" (savings banks) and "Genossenschaftsbanken" (cooperative banks/credit unions) in Germany are good examples of this position (Herr/ Stachuletz 2010a).

The government should influence credit allocation in order to be able to pursue industrial policy aims. For this purpose special banks make sense, which are separate from normal banking. Policy credits should be made transparent and reserved for special purposes.

The central bank should also have the instruments needed to influence credit allocation from a macro-economic point 
of view, for instance to limit or boost the credit volume for the housing sector in specific situations.

An important step towards an increase of professionalism and independence of the banking system is to disentangle financial institutions that are linked to state-owned companies or private institutions. In addition, the banking system should be reformed in a way that small businesses can be provided with loans and financial services. For this the development of microcredit institutions should also be considered.

In a country like Vietnam the banking system should be at the centre of company financing, while the stock market can strengthen companies' equity status by issuing new shares. The stock market should receive support for this, whereas borrowing from banks for speculation purposes must be prevented. Complicated derivatives should notplay a role for countries like Vietnam.

\section{Governance}

It is never quite clear what is meant by good governance. After the experience of the sub-prime mortgage crisis, the simple transfer of western institutions to Vietnam is obviously not a solution. Vietnam needs to seek a transparent and productive interaction between markets and state control or regulation. There is no secret recipe here but rather country-specific solutions. Corruption in the form of a hidden scale of fees can be made transparent and converted into a more binding system of charges. Corruption influences important decisions within the society, endangers social coherence and must be opposed forcefully.

\section{References}

Chang, H.-J. (2002): Kicking Away the Ladder, Anthem.

Dullien, S., Herr, H., Kellermann, C. (2009):

Der gute Kapitalismus, Transcript, Bielefeld.
General Statistics Office Of Vietnam (2010) - Statistics Documentation Centre (GSO) Ba Dinh Ha, Noi, 6B Hoang Dieu, Internet: www.gso.gov.vn

Herr, H. (2008): "Financial Systems in Developing Countries and Economic Development", in: E. Hein, T. Niechoj, P. Spahn, A. Truger (eds.), Finance-led Capitalism? Macroeconomic Effects of Changes in the Financial Sector, Marburg: Metropolis.

Herr, H., Stachuletz, R. (2010): "Die Immobilien-Bubble: Makro- und mikoökoomische Entstehungsmuster nachhaltiger Instabilitäten und Wege aus der Krise", in: M. Kühnbergber, H. Wilke (Hrsg.), Immobilienbewertung. Methoden und Probleme in Rechnungswesen, Besteuerung und Finanzwirtschaft, Schäffer-Poeschel Verlag, Stuttgart, S. 365-394.

Herr, H., Stachuletz, R. (2010a): Reform Options of Financial Systems. Global Labour Column, http://column.globallabour-university.org/

IMF Country Reports Vietnam 2003-2010, Washington D.C.

Stachuletz, R. (2011): Anmerkungen zum Märchen von der optimalen Staatsquote und das Ende der Privatisierungsagenda, to be published Hanoi 2011.

Stiglitz, J.E., Uy, M. (1996): "Financial Markets, Public Policy, and the East Asian Miracle", The World Bank Observer, 11: 249-276.

Transparency International (2010): Corruption Perception Index.

Vietnam News (2010): "Tightened Credit Chills Real Estate Sales", 18 September 2010, Hanoi, p. 17. 